\title{
GAYA PENDIDIKAN 3D MODELLING (CAD/CAID) KE 3D PRINTING SEBAGAI LANGKAH DASAR DESAIN SESUAI REVOLUSI INDUSTRI KE EMPAT
}

\author{
Geggy Gamal Surya \\ Desain Produk, Fakultas Desain \& Industri Kreatif, \\ Universitas Esa Unggul, Jakarta 11510, Indonesia \\ Geggy.gs@esaunggul.ac.id
}

\begin{abstract}
Abstrak
Pendidikan desain industri memerlukan tahapan-tahapan sesuai pada zamannya. Pembelajaran yang dibutuhkan harus sesuai tuntutan zaman yakni kemajuan teknologi yang berfungsi memudahkan dalam aspek penggunaan dan pembuatan dalam bidang desain industri. Desain industri memiliki tahapan dasar, yaitu ide, konsep, gambar sketsa, proyeksi tiga dimensi, pemodelan skala dan mockup atau prototipe. Dalam tiap tahapan tersebut, perkembangan yang mempunyai pengaruh besar adalah tahapan proyeksi tiga dimensi. Proyeksi tiga dimensi tidak hanya sekedar membuat model dan menciptakan hasil render, tapi sudah pada kepada hasil nyatanya yaitu masuk ke ranah $3 D$ mockup/3D prototipe melalui 3D Printer yang disebut sebagai 3D Printing. Pentingnya pendidikan seperti Universitas, Sekolah Tinggi, Akademi maupun tempat-tempat kursus yang memiliki mata pembelajaran ini, wajib menyertakan pendidikan 3D Printing ke dalam mata pembelajaran/ mata kuliah 3D Modelling (CAD/CAID). Memasuki era Revolusi Industri Keempat tentu memerlukan beberapa update pada masing-masing mata pembelajaran pada pendidikan desain industri, hal ini karena berkaitan dengan unsur teknologi dalam dunia desain industri yaitu mesin Printer 3D. Saat ini, sangat dibutuhkan lapangan pekerjaan yang membutuhkan operator mesin 3D Printer yang muncul dari lulusan-lulusan desain produk/ desain industri. Operator yang dimaksud adalah lulusan yang menguasai software $3 D$ Modelling. Lulusan tersebut harus dibubuhi ilmu dalam pengoperasian mesin 3D Printer yang berkaitan erat dengan CAD/CAID dalam diploma maupun Strata Satu. Sehingga dapat menciptakan lulusan yang berkompeten dan menjadi pekerja yang sangat dibutuhkan di perusahaan yang mengaplikasikan teknologi-teknologi Revolusi Industri Keempat.
\end{abstract}

Kata kunci : 3D Modelling, 3D Printing, Desain Industri, Desain 3D 
Geggy Gamal Surya, Gaya Pendidikan 3D Modelling (CAD/CAID) Ke 3D Printing Sebagai Langkah Dasar Desain Sesuai Revolusi Industri Ke Empat

Abstract

Industrial design education requires stages according the timeline of the era. The learning needed must be in accordance with the demands of the era, ie technological advancements that function to facilitate aspects of the use and manufacture in the field of industrial design. Industrial design has basic stages, ie ideas, concepts, sketch drawings, three dimensional projections, scale modeling and mockups or prototypes. In each of these stages, developments that have a large influence are the stages of three dimensional projection. The 3-dimensional projection is not just making a model and creating a rendering result, but it has turned to the real results of entering the $3 D$ mockup / $3 D$ prototype through $3 D$ Printer which is called $3 D$ Printing. The importance of education such as Universities, Colleges, Academies and course places that have this subject of study, must include $3 D$ Printing education into the subject of learning / 3D Modeling (CAD / CAID) courses. Entering the fourth industrial revolution era certainly requires some updates on each subject of learning in industrial design education, this is because it is related to technological elements in the world of industrial design ie $3 D$ Printing machine. At present, jobs are urgently needed that require $3 D$ Printer machine operators to emerge from graduates of product design / industrial design. Approved operators are those who understand $3 D$ Modeling software. These graduates must be knowledgeable in the operation of $3 D$ Printer machines that are closely related to CAD / CAID in diploma or bachelor degree. So that it can create competent graduates who are needed workers in companies that apply fourth industrial revolution technologies.

Keywords : 3D Modelling, 3D Printing, Industrial Design, 3D Design

\section{Pendahuluan}

3D atau yang disebut Tiga Dimensi atau Tiga Dimensional adalah suatu objek yang berhubungan dengan penglihatan, atau pemandangan yang terbentuk dari tiga garis perspektif, terbentuk dalam dunia nyata maupun dunia maya. Dalam dunia nyata, 3D terbentuk dari sudut pandang yang lebih tinggi (posisi melihat dari atas) sehingga menciptakan tiga garis perspektif. Dalam dunia maya, adalah sesuatu yang terbentuk melalui "objek" yang dibentuk dari perangkat lunak (software) komputer. Dunia tiga dimensi melalui dunia maya sudah berkembang dari era komputer Windows 93/98. Tiga Dimensi sudah diadopsi dari film-film Hollywood, sebut saja film Back to the future, Jurassic Park, Fifth Element, dan lain sebagainya. Pembuatan film tersebut sudah melibatkan peran komputer dari perangkat lunak tiga dimensi. Tiga Dimensi digunakan sesuai kebutuhan, ada yang untuk Entertainment, untuk Industrial, untuk Architecture, 24 untuk landscape, dan untuk yang lain-lain yang berkaitan dengan tiga dimensi. Pada masa sekarang yang sudah memasuki era Revolusi Industri Keempat, yang paling berkembang dalam hubungan Revolusi Industri Keempat adalah segmen industrial. Industrial dalam tiga dimensi adalah sebuah objek yang berkaitan dengan sebuah produk. Produk yang dimaksud berupa alat kesehatan, sepatu, kacamata, part mesin, dan lain-lain. Tidak dipungkiri bahwa era Revolusi Industri Keempat memerlukan pendidikan dasar desain yang sudah harus memiliki standarisasi dalam penciptaan dan pembuatan. Memasuki era Revolusi Industri Keempat, dibutuhkan pembelajaran yang mengkhususkan mata kuliah 3D Printing ini kedalam kurikulum program studi desain produk/desain industri. Memang 3D Printing cukup dipelajari dalam hitungan jam dalam menguasai operating system-nya tapi tidak cukup dalam aspek pendalaman ma- 
Vol. 7, No. 1, Oktober 2019

teri akan ilmu pengetahuan tentang filsafat desainnya. Dibutuhkan waktu dalam mengkajinya dimana sekarang 3D Modelling sudah ber-partner dengan mesin 3D Printing dimana sebelumnya harus dengan mesin $\mathrm{CNC}$ yang harus juga menggunakan Computer Aided Manufacturing (CAM) yang banyak menggunakan banyak waktu dalam masa pra-produksinya.

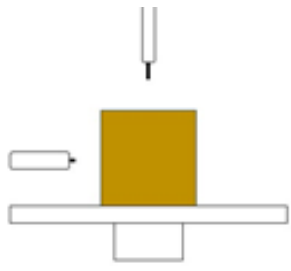

Gambar 1. Mesin CNC dengan 'Object Centered'

Mesin CNC dapat dikatakan mesin 3D Printing, tapi karena basisnya bukan mesin printing, akan tapi lebih dominan kepada mesin cetak karena tidak bisa langsung dari komputer (tidak universal). Dengan mulainya ada penemuan mesin 3D Printing, maka setiap software tiga dimensi dapat merubah hasil 3D Modelling ke Rapid Prototyping ke mesin 3D Printing.

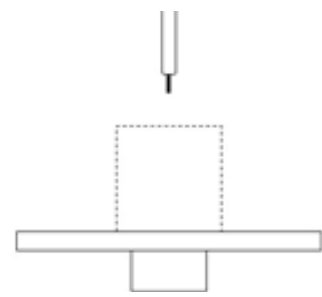

Gambar 2. Mesin 3D Printing dengan 'Empty Object'

Dengan adanya penemuan mesin printer 3D, maka era Revolusi Industri Keempat atau 4IR (Fourth Industry Revolution) dimulai.

\section{Metode Penelitian}

Dengan melihat adanya definisi dari arti kata modelling tiga dimensi dan printing tiga dimensi disini, maka keutamaan penelitian ini adalah memberi pandangan tentang pentingnya transisi 3D modelling ke proses 3D printing dengan konsep pendidikan dasar desain sesuai pergerakan Revolusi Industri Keempat. Pertegasan penelitian ini adalah merancang dalam meredefinisi pendidikan dasar keilmuan desain industri dengan teknologi yang serba instan dan cepat, sehingga masyarakat, peneliti, desainer dan pelaku akademik yang ingin memperbarui definisi tiga dimensi dapat diolah menjadi standar pembelajaran sistem tiga dimensi. Ilmu tentang tiga dimensi mengenai metode penciptaan desain produk/ desain industri masih sedikit di Indonesia, maka dari itu dengan penjelasan disini agar mahasiswa-mahasiswi yang mempelajari ilmu desain industri dapat memahami tentang tiga dimensi dalam era Revolusi Industri Keempat yang sudah terintegrasi dengan mesin-mesin rapid prototyping. Tidak luput vendor-vendor mesin 3D Printing harus terlibat dengan pihak akademik dalam meredefinisi pendidikan tiga dimensi ini.

\section{3D Modelling}

Dibangun dari Computer Aided Design (CAD) agar membentuk suatu desain yang diinginkan. CAD adalah suatu proses dengan penggunaan komputer dan merupakan perangkat lunak spesialis dalam menciptakan model virtual tiga dimensi yang diambil dari bentuk model dua dimensi yang berupa gambar manual. CAD memiliki beberapa jenis tipe dalam pengembangannya, ada yang berupa Computer Aided Industrial Design (CAID), Computer Aided Manufacturing (CAM) dan lain sebagainya tergantung dari kebutuhan penggunanya. Dengan adanya software 3D Modelling, desainer produk dapat mengembangkan idenya dengan cepat, lebih efisien, lebih realistis dan dengan mudahnya membuat prototipe secara akurasi melalui media tiga dimensi. 
Geggy Gamal Surya, Gaya Pendidikan 3D Modelling (CAD/CAID) Ke 3D Printing Sebagai Langkah Dasar Desain Sesuai Revolusi Industri Ke Empat

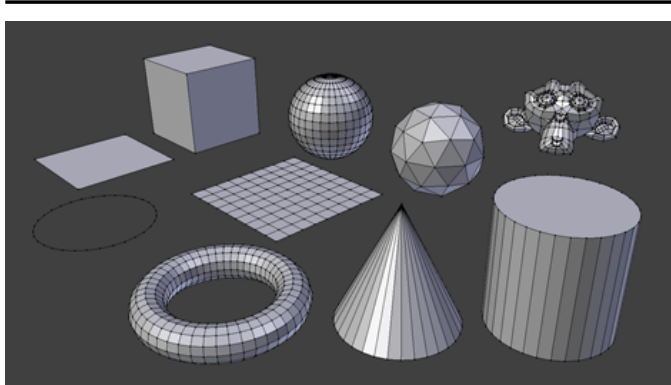

Gambar 3. 3D Modelling dalam bentuk sederhana

\section{Revolusi Industri Keempat}

Revolusi Industri Keempat dibangun di atas revolusi digital, mewakili cara-cara baru ketika teknologi menjadi tertanam dalam masyarakat dan bahkan tubuh manusia. Revolusi Industri Keempat ditandai dengan munculnya terobosan teknologi di sejumlah bidang, termasuk robotika, kecerdasan buatan, nanoteknologi, komputasi kuantum, bioteknologi, internet of things (IoT), pencetakan 3D dan kendaraan otonom (autonomous vehicles). Frasa "Revolusi Industri Keempat" pertama kali diciptakan oleh Schwab pada tahun 2016, dan diperkenalkan pada tahun yang sama di World Economic Forum. Revolusi Industri Keempat memiliki kesempatan unik untuk meningkatkan komunikasi manusia dan resolusi konflik. Teknologi dan era ini akan mengubah cara kita hidup dan bekerja.

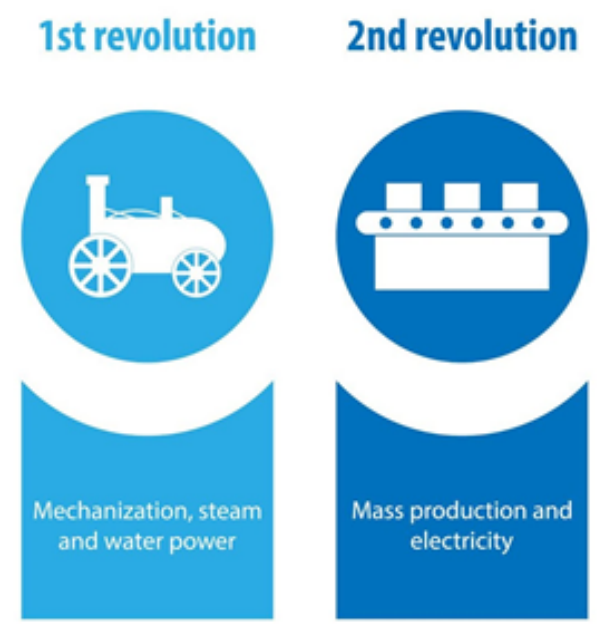

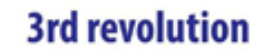

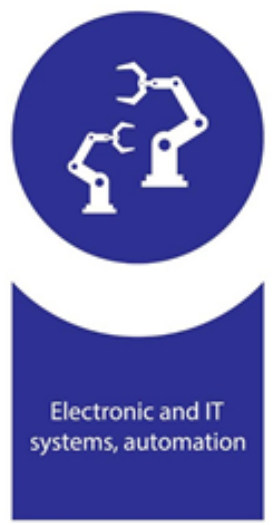

\section{4th revolution}

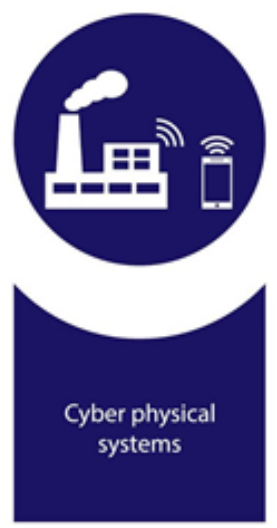

Gambar 4. Perjalanan Revolusi Industri 
Vol. 7, No. 1, Oktober 2019

\subsection{Printer 3D}

Printer 3D adalah jenis printer desain material yang dirancang dan membuat model 3D. Printer 3D juga merancang dan membuat perangkat serta komponen menggunakan proses pembuatan aditif. Printer 3D mendesain prototipe tiga dimensi dan membuat produk akhir, kemudian langsung membangunnya menggunakan Computer Aided Design (CAD) atau diagram, angka, dan pola desain 3D yang dibuat oleh perangkat lunak. Printer 3D juga dapat disebut printer manufaktur aditif atau printer fabrikasi. Printer 3D digunakan untuk membangun dan memungkinkan pembuatan prototipe yang cepat dari objek dan struktur tiga dimensi menggunakan file dari aplikasi perancangan 3-D seperti Autodesk Alias, AutoCAD, Sketchup, dll. Printer 3D menghilangkan kebutuhan untuk proses pemesinan, juga mengurangi tugas-tugas seperti memotong dan menggilas, sehingga produk akhir bisa dibangun dalam tiga dimensi tanpa limbah. Pemesinan seperti memotong atau menggilas adalah era Revolusi Industri Ketiga sehingga dengan munculnya Revolusi Industri Keempat memudahkan kita untuk bekerja dan penuh dengan kreativitas yang baru.

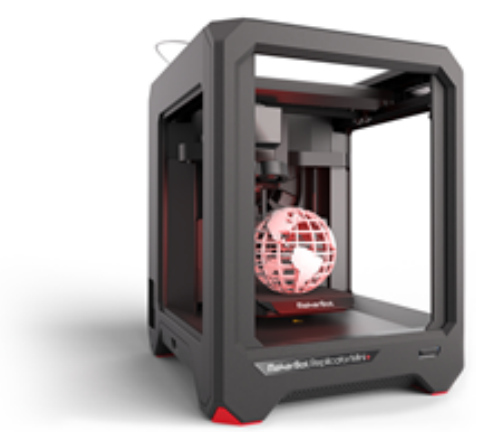

Gambar 5. Mesin Printer 3D

\subsection{Manfaat Pencetakan 3D}

Manfaat yang dihasilkan dari pencetakan mesin Printer 3D adalah mudahnya menciptakan desain produk-produk melalui berbagai bidang, diantaranya :

\subsubsection{Industri Kedirgantaraan}

Pencetakan 3D memungkinkan perusahaan kedirgantaraan untuk membuat komponen kompleks yang sebelumnya tidak mungkin dilakukan dengan teknik tradisional. Hal ini mendorong inovasi sambil mengurangi biaya dan waktu penyelesaian di lingkungan yang kompleks dan sangat dikendalikan. Industri kedirgantaraan adalah kandidat utama yang mendapatkan manfaat dari pencetakan 3D. Teknologi ini memberikan perusahaan fleksibilitas untuk mencetak bagian pesawat tertentu untuk diaplikasi dalam jumlah ratusan atau ribuan tanpa perubahan peralatan yang mahal.



Gambar 6. Mencetak turbin dengan 3D printing technology

\subsubsection{Bidang Arsitektur}

Arsitektur adalah salah satu bidang di mana pencetakan 3D menjadi berita besar, dan akan terus berlangsung di tahun-tahun mendatang. Selain mengeksplorasi potensi masa depan, tentunya tetap ada keterbatasan pencetakan 3D saat ini dalam industri kontruksi. Dari sisi klien atau prospek, gambar 2D yang datar tidak banyak bercerita tentang bagaimana struktur akhir akan terlihat. Inilah sebabnya mengapa arsitek menggunakan tayangan artistik dan model 3D untuk mengilustrasikan kreasi mereka. Di masa lalu, pembuatan maket tiga dimensi merupakan pekerjaan yang panjang dan mele- 
lahkan. Sering kali, arsitek harus kembali mengobrak-abrik gambar untuk mengubah dan modifikasi desain. Di masa depan, seluruh proses ini akan menjadi lebih cepat, lebih mudah, lebih efisien dan lebih murah berkat kemajuan teknologi pencetakan 3D.

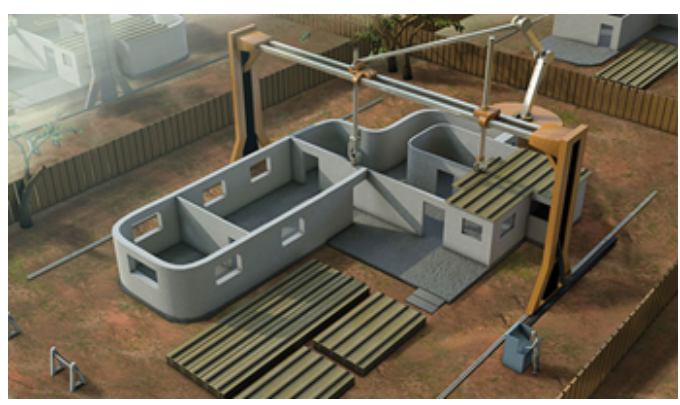

Gambar 7. Mencetak rumah dengan mesin 3D Printing raksasa

\subsubsection{Bidang Kedokteran}

Pencetakan 3D dalam bidang medis, atau dikenal sebagai bioprinting, pernah menjadi impian ambisius. Namun, waktu dan investasi akhirnya membuatnya menjadi kenyataan. Sekarang, Printer 3D membantu perusahaan farmasi untuk membuat obat yang lebih spesifik, memungkinkan produksi implan medis secara cepat, dan mengubah cara dokter dan ahli bedah merencanakan prosedur. Tujuan utama pencetakan 3D medis adalah untuk membuat organ pengganti untuk pasien manusia, tetapi ini hanyalah salah satu aplikasi potensinya. Pencetakan 3D bagi perawatan kesehatan masih merupakan penelitian yang terus diperbaharui, tetapi sudah diterapkan dalam banyak cara. Bagaimanapun juga pencetakan 3D akan mengubah industri kesehatan dan mempengaruhi masa depan perawatan kesehatan.

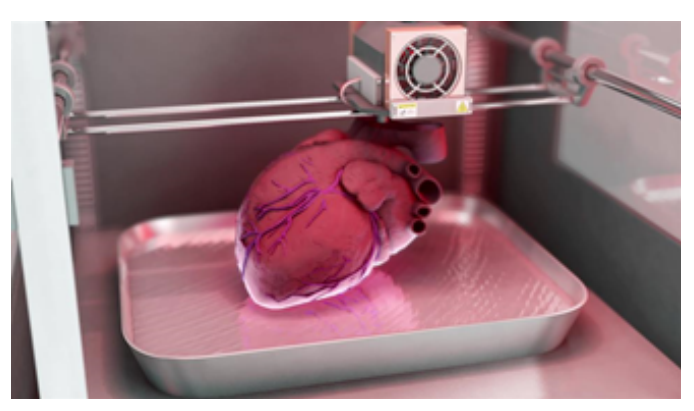

Gambar 8. Mencetak organ tubuh dengan mesin 3D Printing

\subsubsection{Bidang Desain Industri}

Sangat mempengaruhi kinerja seorang desainer produk, karena saat sekarang desainer produk lebih mengutamakan system 'function follow form' dari pada metode lama yaitu 'form follow function'. Istilah ini terkenal dalam dunia desain industri. Mengikuti perkembangan Revolusi Industri Keempat, dimana sekarang 'fungsi wajib mengikuti bentuk' ketimbang dalam Revolusi Industri Ketiga bahwa 'bentuk wajib mengikuti fungsi' karena keterbatasan teknologi. Bisa diambil contoh seperti desain alas kaki sepatu (footwear design), pembuatan melalui pencetakan 3D dapat dilakukan dengan mudah melalui kreasi desainer produk yang terintegrasi dengan desain materialnya. Sepatu dengan mudah dibuat di Printer 3D dengan menggunakan bahan filaflex, yaitu bahan yang dapat dipakai sebagai alas kaki yang mengandung unsur fleksibilitas.

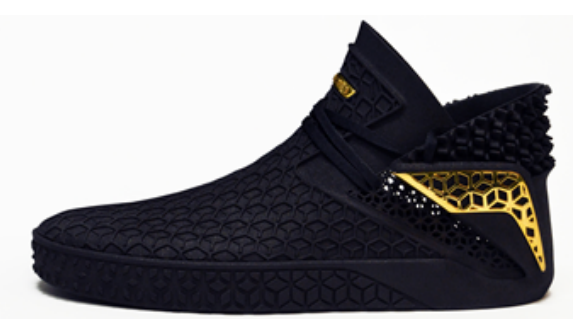

Gambar 9. Membuat sepatu dengan menggunakan mesin 3D Printing 
Vol. 7, No. 1, Oktober 2019

V. Pengaruh Revolusi Industri Keempat

Klaus Schwab mengungkapkan

bahwa Revolusi Industri Keempat dapat menjadi titik temu bagi makna tradisional manusia (pekerjaan, masyarakat, keluarga, dan identitas) atau dapat meningkatkan rasa kemanusiaan menjadi kesadaran kolektif dan moral baru berdasarkan pada perasaan takdir bersama. Ungkapan ini memiliki pengaruh pada tiap kategorinya.

\subsection{Pengaruh pada Masyarakat/Indivi-} du

Teknologi baru dapat menjadi agen perubahan yang kuat untuk selamanya. Pendidikan dan akses ke informasi dapat meningkatkan kehidupan miliaran orang di dunia. Perangkat dan jaringan komputasi yang semakin kuat, layanan digital, serta perangkat seluler dapat menjadi kenyataan bagi orang-orang di seluruh dunia, termasuk penduduk di Negara-negara terbelakang. Revolusi media social, seperti facebook, twitter, instagram, dll, memberikan pengaruh kepada semua orang dengan cara berkomunikasi secara langsung. Media social dapat membawa kita mengakses produk dan layanan ke model pasar yang benar-benar baru. Layanan belanja dan pengiriman online, termasuk yang dilakukan menggunakan drone, membentuk ulang pemahaman akan kenyamanan dan pengalaman ritel. Kemudahan pengiriman mengubah masyarakat, bahkan yang tinggal di tempat-tempat terpencil, dan memacu ekonomi pedesaan atau daerah yang terpencil.

\subsection{Pengaruh pada Teknologi}

Revolusi Industri Keempat diharapkan dapat mempengaruhi aspek peningkatan produk. Dalam aspek peningkatan produk, teknologi siber-fisik seperti pencetakan 3D memungkinkan produsen untuk bereksperimen dengan desain produk baru secara cepat dan biaya lebih efektif. Tanpa membutuhkan cetakan dan perkakas, pencetakan 3D memungkinkan produsen untuk membuat satu prototype dengan biaya yang sama seperti pembuatan model produksi. Ini membuka peluang bagi produsen untuk bereksperimen dengan desain inovatif dan membuat produk khusus untuk memenuhi kebutuhan pengguna individu.

\subsection{Pengaruh pada Bisnis}

Salah satu dampak utama Revolusi Industri Keempat (4IR) adalah peningkatan produktivitas manusia. Dengan teknologi seperti Artificial Intelegence (AI) dan otomatisasi yang menambah kehidupan profesional, kita dapat membuat pilihan cerdas dan lebih cepat daripada sebelumnya. Dampak dari 4IR tidak selalu hebat, ada beberapa implikasi moral dan etika yang besar dan kuat bagi inovasi-inovasi tersebut.

\section{Masa Depan 3D}

Menurut laporan World Economic Forum Technology Tipping Point, titik tipping yang berhubungan dengan teknologi 3D berikut dapat terjadi pada tahun 2025 :

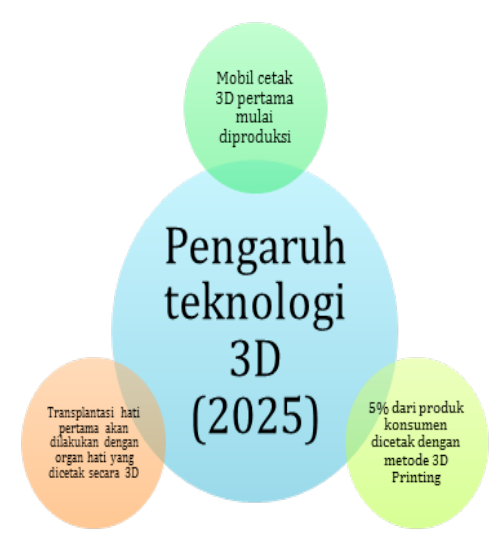

Gambar 10. Masa depan teknologi 3D pada tahun 2025 sesuai data WEFT 
Geggy Gamal Surya, Gaya Pendidikan 3D Modelling (CAD/CAID) Ke 3D Printing Sebagai Langkah Dasar Desain Sesuai Revolusi Industri Ke Empat

Dari data yang dikemukakan oleh WEFT, era Revolusi Industri Keempat memang sudah tidak bisa lagi dihindarkan dikarenakan teknologi yang sudah berjalan saat ini. Belum lagi adanya penemuan kesempurnaan dalam teknologi sehingga semua industri-industri yang ada berjalan dengan lebih efisien dan lebih mengutamakan sistem robot yang sudah terintegrasi dengan jaringan $4 \mathrm{G}$ bahkan $5 \mathrm{G}$. Dengan masa depan printer 3D, tentu pendidikan ini harus ditata dengan baik dengan mengikuti sejarah yang ada sehingga penataan pendidikan dasarnya mengikuti alur yang sudah tercipta yang berawal dari pembelajaran keilmuan 3D modelling. 3D printing tidak akan tercipta apabila tidak ada 3D modelling.

\section{Kesimpulan}

Pada era Revolusi Industri Keempat, 3D Printing sudah menjadi standar industri dalam menciptakan sebuah produk secara efisien dan inovatif demi memenuhi kebutuhan masyarakat saat ini. 3D Printing adalah jawaban memenuhi tantangan era Revolusi Industri Keempat khususnya dunia desain industri. Dengan adanya perangkat ini, kewajiban dunia pendidikan menghadapi era Revolusi Industri Keempat harus menjadi basis standar dasar pendidikan keilmuan desain yang harus disodorkan kepada mahasiswa dan mahasiswi desain produk/industri berupa pendidikan desain industri sebagai operator 3D Printing (operator 3D Printing adalah yang menguasai software 3D Modelling). Sebab, sudah menjadi tuntutan zaman revolusi industri. Tiap Universitas yang memiliki program studi desain produk sudah harus membubuhi pentingnya mata kuliah '3D Printing'. Pentingnya mahasiswa-mahasiswi bereksperimen dengan mesin 3D Printing adalah untuk menguasai bagaimana mengatur, mengukur, mengendalikan dan menyunting aplikasi output tersebut. Pendidikan desain ini harus menjadi dasar pembekalan keilmuan desain industri pada awal mula Revolusi Industri
Keempat yang menempatkan posisi mesin 3D Printing sebagai prioritas untuk para desainer produk masa depan. 


\section{Daftar Pustaka}

Bryden, Douglas. 2014, CAD nad Rapid Prototyping for Product Design, Laurence King Publishing Ltd, London.

Heskett, John, 1986, Desain Industri, CV. Rajawali, ITB

Lidwell, William \& Kritina Holden, Jill Butler. 2010, Universal Principles of Design, Rockport

Publishers, USA.

O’Donnell, Kevin, 2003, Postmodernisme, Lion Publising, Oxford.

Savitri, Astrid. 2019, Revolusi Industri 4.0 Mengubah Tantangan Menjadi Peluang di Era Disrupsi 4.0., Penerbit Genesi, Depok. 